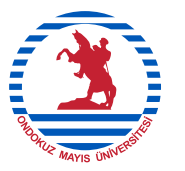

Samsun Sağlık Bilimleri Dergisi,

Journal of Samsun Health Sciences

ISSN: 2458-8857 e-ISSN: 2791-9722, JSHS December 2021, 6(3): 573-584

\title{
Insomnia Severity of Academicians Working in Health Sciences in Coronavirus Pandemic
}

\section{Koronavirüs Pandemisinde Sağlık Bilimleri Alanında Çalışan Akademisyenlerin Uykusuzluk Şiddeti}

\author{
Serap ÖZTÜRK ALTINAYAK'1, Tülay YILMAZ BINGÖL², Zümrüt YILAR ERKEK³ \\ 1 Ondokuz Mayıs University Faculty of Health Science, Department of Midwifery, Kurupelit Campus, 55200, \\ Samsun, Turkey, \\ • serapozturk88@hotmail.com• ORCiD > 0000-0002-3882-0966 \\ ${ }^{2}$ Tokat Gaziosmanpaşa University Faculty of Health Science, Department of Nursing, Taşlıçiftlik Campus, 60250 \\ Tokat, Turkey, \\ • tulayyilmazbingol@gmail.com• ORCID > 0000-0002-3552-7166 \\ ${ }^{3}$ Tokat Gaziosmanpaşa University Faculty of Health Science, Department of Midwifery, Taşlıçiftlik Campus, 60250 \\ Tokat, Turkey \\ •zyilar@hotmail.com• ORCiD > 0000-0002-0495-9003
}

\section{Makale Bilgisi / Article Information}

Makale Türü / Article Types: Araştırma Makalesi / Research Article

Geliş Tarihi / Received: 14 Ağustos / August 2021

Kabul Tarihi / Accepted: 17 Kasım / November 2021

YIl/Year: 2021 | Cilt - Volume: 6 | Sayı - Issue: 3 | Sayfa / Pages: 573-584

Atıf/Cite as: Öztürk Altınayak, S., Yılmaz Bingöl, T. ve Yılar Erkek, Z. "Insomnia Severity Of Academicians Working In Health Sciences In Coronavirus Pandemic - Koronavirüs Pandemisinde Sağlık Bilimleri Alanında Çalışan Akademisyenlerin Uykusuzluk Şiddeti". Samsun Sağlık Bilimleri Dergisi- Journal of Samsun Health Sciences 6(3), Aralık 2021: 573-584. https://doi.org/10.47115/ jshs. 982299

Sorumlu Yazar: Serap ÖZTÜRK ALTINAYAK

Copyright @ Published by Ondokuz Mayıs Üniversitesi, Sağlık Bilimleri Fakültesi - Ondokuz Mayıs University, Faculty of Health Sciences, Samsun, Turkey. All rights reserved. 


\section{INSOMNIA SEVERITY OF ACADEMICIANS WORKING IN HEALTH SCIENCES IN CORONAVIRUS PANDEMIC}

\section{ABSTRACT:}

Aim: The aim of this study is to determine the severity of insomnia of academicians working in the field of health sciences in the COVID-19 pandemic.

Method: This research in descriptive design was conducted between 20 March - 31 May 2020 with 114 academic staff working in the field of Health Sciences of a university in the Black Sea Region. "Questionnaire form" and "Insomnia Severity Index (ISI)" were used to collect the data. Number, percentage distribution, mean, standard deviation, one way anova and unpaired t test were used to evaluate the data.

Results: In the study, the average score of ISI of academicians was $10.40 \pm 5.50$, female had 11.24 \pm 5.44 , male had 9.77 \pm 5.50 , research assistants had $13.46 \pm 3.92$ and those with any ailments had an average score of $10.72 \pm 6.01$. No statistically significant differences were found between gender, academic title, and having any ailment and ISI ( $p>0.05)$. When evaluated according to the breakpoints of the scale, it was found that $44.7 \%$ of the academicians had the lower threshold of insomnia, $22.8 \%$ had moderate clinical insomnia, and $0.9 \%$ had severe clinical insomnia.

Conclusion and Suggestions: In the study, it was found that female academicians, research assistants and academicians with any ailments were exposed to insomnia at a higher rate. In addition, it was determined that almost half of the academicians were at the lower threshold of insomnia.

Keywords: Academician; Midwifery; Nursing; Health Sciences; Insomnia

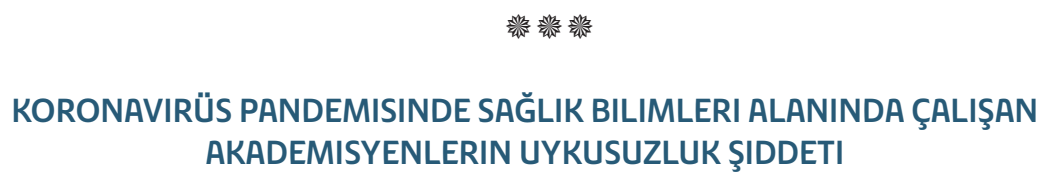

ÖZ:

Amaç: Bu araştırmanın amacı COVİD-19 pandemisinde sağlık bilimleri alanında çalışan akademisyenlerin uykusuzluk şiddetini belirlemektir.

Yöntem: Tanımlayıcı tasarımda yapılan bu araştırma 20 Mart - 31 Mayıs 2020 tarihleri arasında, Karadeniz Bölgesinde bir üniversitenin Sağlık Bilimleri alanında 
çalışan 114 akademik personel ile yürütülmüştür. Verilerin toplanmasında "Anket formu” ve “ Uykusuzluk Şiddet İndeksi (UŞİ)" kullanılmıştır. Verilerin değerlendirilmesinde; sayı, yüzdelik dağılım, ortalama, standart sapma, one way anova ve bağımsız örnekler t testi kullanılmıştır.

Bulgular: Araştırmada akademisyenlerin UŞİ toplam puan ortalamasının $10.40 \pm 5.50$ olduğu, kadınların 11.24 \pm 5.44 , erkeklerin $9.77 \pm 5.50$, araştırma görevlilerinin $13,46 \pm 3,92$ ve herhangi bir rahatsılı̆ğ olanların $10.72 \pm 6.01$ puan ortalamasına sahip olduğu görülmüsstür. Cinsiyet, akademik ünvan ve herhangi bir rahatsızlığı olma durumu ile UŞİ arasında istatistiksel olarak anlamlı fark bulunmamıştır ( $p>0.05$ ). Ölçeğin kesme noktalarına göre değerlendirildiğinde ise akademisyenlerin \%44.7'sinin uykusuzluk alt eşiğine, \%22.8'inin orta düzeyde klinik uykusuzluğa, \%0.9’unun şiddetli klinik uykusuzluğa sahip olduğu saptanmıştır.

Sonuç ve Önerileri: Araştırmada kadın akademisyenlerin, araştırma görevlilerinin ve herhangi bir rahatsızlığı bulunan akademisyenlerin daha yüksek uykusuzluğa maruz kaldığı saptanmıştır. Ayrıca akademisyenlerin yarısına yakınının uykusuzluk alt eşiğinde olduğu belirlenmiştir.

Anahtar Kelimeler: Akademisyen; Ebelik; Hemşirelik; Sağlık Bilimleri; Uykusuz-
luk

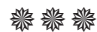

\section{INTRODUCTION}

Epidemics throughout history have caused various psychological effects not only on those who suffered from the disease but also on the general public (Sögütlü et al., 2021). COVID-19 pandemic that emerged first in December of 2019 in the World and in Turkey on 10 March 2020, showed a very rapid spread and influenced the whole world. When the World Health Organization declared this epidemic as a pandemic, physical health problems caused by the disease increased. In addition to physical health problems, psychological problems related to the pandemic also started to appear in the society. Studies showed that the increase in the number of cases in this period caused many psychological problems in the whole society, including panic, anxiety, fear, depression and stress (Bakioğlu et al., 2020; Liu et al., 2020; Özdin \& Bayrak Özdin, 2020; Rubin \& Wesseley, 2020).

Sleep disorder is a health problem that can be seen frequently and can cause morbidity (Javadzade, 2018). Insomnia can be defined as a sleep disorder manifested by difficulty falling asleep and not being able to sleep again after waking up frequently (Köroğlu, 2013). In the literature, it has been reported that inadequate 
sleep poses a threat to health as well as causes a decrease in cognitive, psychomotor and emotional functions, impairs the immune system due to disruption of sleep-related hormonal balance, and causes more frequent and severe health problems (Besedovsky et al., 2012; İlhan Alp et al., 2020). On the other hand, there are studies indicating that stress also has a negative effect on sleep (Alvaro et al., 2013; Johnson et al., 2006; Van Reeth et al., 2000). Pandemic period is an important factor that causes stress on people. In this period, in addition to the daily stresses of people, problems such as illness caused by the pandemic, loss of relatives, financial difficulties, and changing life routine can also cause individuals to experience insomnia as an additional stressor. The term "COVID-Somnia" has also started to take place in the literature to describe these sleep disorders experienced during the pandemic period (Gupta \& Pandi-Perumal, 2020). It makes us think that these sleep disorders caused by the pandemic can now be seen in our lives or in the people around us.

Health professionals, who are in close contact with the society, can offer supportive and preventive health services individually and socially to cope with the negative effects of insomnia on both individuals and society. Especially in this period, the statement that midwives, nurses and physicians can take part in the scope of control of infectious diseases and preventive mental health services, which is mentioned in the "Regulation of Community Health Center and Affiliated Units" of the Ministry of Health, requires especially the training of these occupational groups, increasing their awareness and to know current situation (Turkish Public Health İnstitution, 2015; Turkish Ministry of Health, 2018). Especially during the COVID-19 pandemic period that health professionals from all branches are most needed, it is important to identify insomnia problems for the academicians working in the field of health sciences, who are responsible for the education of these service branches, in order to maintain their own health.

Studies on the severity of insomnia were encountered in the literature review (Ayyıldız \& Ayyıldız, 2019; Beşirli, 2020; Şahiner \& Hisar, 2018). However, although research has been conducted in groups such as university students and healthcare professionals on the problem of insomnia during the COVID 19 pandemic period, no research has been encountered on the severity of insomnia of academicians working in the field of health sciences during this period (Ataç et al., 2020; İlhan et al., 2020; Salcan \& Sarkkaya, 2020; Scotta et al., 2020;). For this reason, this research was conducted to determine the severity of insomnia of academicians working in the field of health sciences in the COVID-19 pandemic. 


\section{MATERIALS AND METHODS}

The place and time of the research: This study was conducted in Tokat Gaziosmanpaşa University Faculty of Health Sciences (Midwifery, Nursing, Physio-therapy and Rehabilitation, Nutrition and Dietetics, Emergency Aid and Disaster Management ...), Faculty of Medicine (Anatomy, Biochemistry, Internal Medicine, Gynecology ...) and Vocational Schools of Health Services (Health Services, Care Services, Medical Services and Techniques, Child Care and Youth Services...) between 20 March - 31 May 2020 with academic staff.

Research sample and population: The population of the research consists of 394 academic staff working in the relevant field at the mentioned university. The random sampling method, one of the improbable sampling methods, was used in the study (Esin, 2015). With this sampling method, the research was conducted with 114 academic staff who accepted to participate in the study.

Data Collection Tools: The data of the study were collected using the "Questionnaire Form" and "Insomnia Severity Index".

Questionnaire Form: It includes some socio-demographic questions such as age, gender, academic title of people in line with the literature (Salcan \& Sarıkaya, 2020; Scotta et al., 2020; Sögütlü et al., 2021) by the researchers.

Insomnia Severity Index (ISI): The Turkish validity and reliability of the scale developed by Bastien et al.(2001) was carried out by Boysan et al. (2010). The scale consists of 7 items and each item is scored between $0-4$ points, and the total score varies between 0-28 points. As the score obtained from the scale increases, it indicates that the sleep problem is at a serious level. The scale has breakpoints and it is expressed as "0-7 points = Clinically insignificant insomnia", "8-14 points $=$ Insomnia lower threshold", "15-21 points = Clinical insomnia (moderately severe)", "22-28 points = clinical insomnia (severe)". The Cronbach alpha value of the scale was reported as 0.79 (Boysan et al., 2010). In this study, the cronbach alpha value of the scale was found to be 0.79 .

Data Collection: The application of the research was done online. Prepared questionnaire form and ISI were uploaded to https://docs.google.com/forms/ and the link address was sent to the e-mails of the academicians who constitute the whole population. An enlightened consent page was presented to the academicians on the introduction page of the questionnaire, and the research was conducted with the academicians who accepted it.

Ethics of the Research: Before starting to collect the research data, ethical 
permission the decision numbered 02.03.2021/01-13 from the Social and Human Sciences Research Ethics Committee of Tokat Gaziosmanpaşa University and the necessary permissions from the Ministry of Health and the institution were obtained. The enlightened consent page was presented to the academicians on the introduction page of the questionnaire and the research was conducted with the academicians who accepted it.

\section{Statistical Method:}

Data were analyzed with IBM SPSS V25. Number, percentage distribution, mean, standard deviation, one way anova and unpaired $t$ test were used to evaluate the data. The significance level was taken as $\mathrm{p}<0.05$.

\section{RESULTS}

The distribution of some introductory characteristics of academicians is given in Table 1. It was found that the average age of the academicians was $39.44 \pm 8.30$, $57.0 \%$ were male, $44.7 \%$ were Assistant Professor, and 59.6\% had no any inconvenience (Table 1).

Table 1. Comparison of Characteristics of Academicians Working in the Field of Health Sciences by Insomnia Severity Index

\begin{tabular}{|c|c|c|c|c|}
\hline Variable $N=114$ & $\mathbf{n}$ & $\%$ & $\begin{array}{c}\text { ISI Total Score } \\
\bar{X} \pm \sigma\end{array}$ & Test statistic \\
\hline \multicolumn{5}{|l|}{ Gender } \\
\hline Male & 65 & 57.0 & $9.77 \pm 5.50$ & \multirow{2}{*}{$\begin{array}{l}\mathrm{t}=-1.423 \\
\mathrm{p}=0.157\end{array}$} \\
\hline Female & 49 & 43.0 & $11.24 \pm 5.44$ & \\
\hline \multicolumn{5}{|l|}{ Title } \\
\hline Research Assistant & 13 & 11.4 & $13.46 \pm 3.92$ & \\
\hline Lecturer & 33 & 28.9 & $10.82 \pm 5.50$ & \\
\hline Assistant Professor & 51 & 44.7 & $10.08 \pm 5.58$ & $\begin{array}{l}\mathrm{F}=2.299 \\
\mathrm{p}=0.063\end{array}$ \\
\hline Associate Professor & 8 & 7.0 & $10.13 \pm 6.22$ & \\
\hline Professor & 9 & 7.9 & $6.56 \pm 4.66$ & \\
\hline \multicolumn{5}{|l|}{ Any Inconvenience } \\
\hline No & 68 & 59.6 & $10.19 \pm 5.17$ & \multirow{2}{*}{$\begin{array}{l}\mathrm{t}=-.499 \\
\mathrm{p}=0.619\end{array}$} \\
\hline Yes & 46 & 40.4 & $10.72 \pm 6.01$ & \\
\hline $\begin{array}{l}\text { Insomnia Severity Index } \\
\text { Total Score Average }\end{array}$ & & & & $10.40 \pm 5.50$ \\
\hline
\end{tabular}

$\mathrm{t}=$ unpaired $\mathrm{t}$ test $\mathrm{F}=$ One Way Anova 
When some characteristics and insomnia severity index scores averages of the academicians were examined, although insomnia severity index score averages found higher when female $(11.24 \pm 5.44)$ were compared to male $(9.77 \pm 5.50)$ and those with any inconvenience $(10.72 \pm 6.01)$ compared to those have no any inconvenience (10.19 \pm 5.17 ), the difference was not statistically significant ( $p>0.05$ ). At the same time, although the insomnia severity index score averages of research assistants $(13.46 \pm 3.92)$ was found to be higher than other titles, the difference was not statistically significant ( $\mathrm{p}>0.05$ ) (Table 1$)$. The total score of the insomnia severity index of the participants was found to be $10.40 \pm 5.50$ (Table 1 ).

When evaluated according to the breakpoints of the insomnia severity index of the academicians, it was determined that $31.6 \%$ had clinically insignificant insomnia, $44.7 \%$ had insomnia lower threshold, $22.8 \%$ had moderate clinical insomnia and $0.9 \%$ had severe clinical insomnia (Table 2).

Table 2. Distribution of Insomnia Severity Index of Academicians Working in the
Field of Health Sciences by Breakpoints
\begin{tabular}{|l|c|c|c|}
\hline Definitions & Cut Points & n & $\%$ \\
\hline Clinically Insignificant Insomnia & $0-7$ & 36 & 31.6 \\
\hline Insomnia Lower Threshold & $8-14$ & 51 & 44.7 \\
\hline Clinical Insomnia (Moderate to Severe) & $15-21$ & 26 & 22.8 \\
\hline Clinical Insomnia (Severe) & $22-28$ & 1 & 0.9 \\
\hline
\end{tabular}

\section{DISCUSSION}

The data obtained as a result of the research were discussed with the relevant literature findings. Although sleep problems differ from society to society, their rates can vary between $5 \%$ and $71 \%$. In the literature, studies conducted on healthcare workers and pharmacy personnel during the pandemic period it was found that the gender variable did not affect the severity of insomnia (Ataç et al., 2020; Salcan \& Sarıkaya, 2020). Also in this study, it was found that the gender variable had no effect on the severity of insomnia. However, there are studies in the literature where the ISI median and mean score of female are higher than male (Salcan \& Sarıkaya, 2020; Sögütlü et al., 2021). Similarly, in this study, female academicians' total ISI score average was found to be higher than male. Due to the division of labor based on gender in Turkey, female had a primary responsibility on issues such as housework and child care. Before the pandemic, OECD (2014) data show that while female spend an average of 4.35 hours a day on routine housework, this period decreases to 21 minutes for male (Bingöl, 2014; OECD, 2014; Şentürk, 2015). Especially during the pandemic period, it is thought that female acemicians have to relinguish their sleep in order to be able to complete their daily work due to the increased responsibilities of female who is working from home or in turn and due to the fact that schools are closed, and the amount of time allocated to housework 
and child care. For this reason, it can be thought that female academicians' ISI scale total scores are higher than male academicians. These findings of the study support the literature findings.

No statistically significant difference was found between academic title and ISI scale total score average. However, the ISI scale total score average of the research assistants was found to be higher than those with other academic titles. It is thought that this situation may have resulted from the fact that research assistants are generally in their education process and they relinguish their sleep in order to be able to complete their duties in the institution they work.

In the study in which Salcan \& Sarıkaya (2020) evaluated the insomnia severity of the personnel working in the pharmacy during the pandemic period, they stated that there was no statistically significant difference between the presence of chronic disease and the ISI. However, the median of those with chronic disease and those without chronic disease were the same (Salcan \& Sarıkaya, 2020). Similarly, in the findings of this research, no statistically significant difference was found between any inconvenience and ISI scale total scores, and the scale total score averages were found to be similar to each other. The research findings support the literature finding.

ISI total score average in the study conducted by Scotta et al (2020) in Covid-19 pandemic period on Argentine university students, scale total score averages in the study conducted by İlhan Alp et al. (2020) among university students in Turkey were found between insomnia lower threshold. Similarly, in this study, when evaluated according to the breakpoints of the index, the ISI total score average was found at the lower threshold of insomnia. The research findings support the findings of the literature.

In the study conducted by Scotta et al. (2020), it was stated that $45 \%$ of the participants had insomnia at the lower threshold, $23 \%$ had moderate clinical insomnia, and $4 \%$ had clinical insomnia. Salcan \& Sarıkaya (2020) stated in their study that $33.3 \%$ were at the lower threshold of insomnia, $17.5 \%$ had moderate clinical insomnia, and $1.6 \%$ had clinical insomnia. In this study, it was found that almost half of the academicians had insomnia lower threshold, approximately one quarter had moderate clinical insomnia, and very few had severe clinical insomnia.

The findings of this research conducted during the pandemic period support each other. Choueiry et al. (2016) reported in a study they conducted before the pandemic that $10 \%$ of the participants had moderate clinical insomnia and $0.2 \%$ had severe clinical insomnia. In another study, it was determined that $55 \%$ of the participants had a lower threshold of insomnia, $10 \%$ had moderate clinical insom- 
nia and no participant with clinical insomnia (Inchausta et al., 2020). It is seen that the rates in the studies conducted before the pandemic are lower than the rates of the studies conducted during the pandemic period. And these research findings are similar to the findings of the literature. As a result, it can be said that the pandemic increases the rate of insomnia in individuals.

\section{CONCLUSION AND SUGGESTIONS}

The impact of the pandemic on humans is clear. Most of the society is adversely affected by the pandemic due to reasons such as the fear of contagion, social isolation, and economic crisis. The impact of the pandemic, especially on female, has been to increase the workload. With the flexible shifts of many professional groups, some of the academicians working in the field of health sciences have switched to flexible shifts. Of course, academic female had to fit their public spaces into their private spaces in this period. It is thought that female sacrifice a lot in order to carry out all these works and they get a small amount of sleep in order to complete these jobs. This study can supports this idea .Especially in the COVID-19 pandemic we are in, the academicians in the field of health sciences, who train qualified health professionals required, experience such problems related to their health as a result of experiencing insomnia problems may affect their professional performance. In order to be aware of the changes in individuals in order to prevent such problems, health professionals such as midwives, nurses and physicians who are in direct contact with the society and female have to deal with both their physical and mental health. In particular, the fact that female are sleep deprived is important not only for their own health, but also for the health of other individuals in the home. Health professionals should be informed about the issue in order to recognize such changes on female and society, and should be able to provide consultancy services to individuals on how to deal with such problems, what they should do or where they can apply. For this, it may be suggested that academicians working in the field of health should include the necessary topics related to the severity of insomnia in their curricula.

Acknowledgments: We thank the academics for their participation.

Authorship Contributions: Consept: SÖA, TYB, ZYE, Design: SÖA, TYB, ZYE, Data Collection or Processing : SÖA ZYE, Analysis or Interpretation: SÖA, TYB, ZYE, Literature Search: SÖA,TYB Writing: SÖA, Critical reading: SÖA, ZYE, TYB,

Conflict of Interest: No conflict of interest was declared by the authors.

Financial Disclosure: The authors declared that this study received no financial support. 


\section{REFERENCES}

Alvaro, P. K., Roberts, R. M., \& Harris, J. K. (2013). A systematic review assessing bidirectionality between sleep disturbances, anxiety, and depression. Sleep, 36(7), 1059-1068. doi:10.5665/sleep.2810

Ataç, Ö., Sezerol, M. A., Taşçı, Y., \& Hayran, O. (2020). Anxiety and insomnia among healthcare workers during the covid-19 pandemic. Türkiye Halk Sağlığı Dergisi, 47-57. doi:10.20518/tjph.767187

Ayyıldız, D., \& Ayyıldız, T. (2019). The relationship of dry eye disease with depressive symptom scores and insomnia. Journal of Turkish Sleep Medicine, 6(2), 49-52. doi:10.4274/jtsm.galenos.2019.46855

Bakioğlu, F., Korkmaz, O., \& Ercan, H. (2020). Fear of covid-19 and positivity: Mediating role of intolerance of uncertainty, depression, anxiety, and stress. International Journal of Mental Health and Addiction, 1-14. doi:10.1007/s11469-020-00331-y

Bastien, C., Vallières, A., \& Morin, C. (2001). Validation of the insomnia severity index as an outcome measure for insomnia research. Sleep Medicine, 2(4), 297-307. doi:10.1016/s1389-9457(00)00065-4

Besedovsky, L., Lange, T., \& Born, J. (2011). Sleep and immune function. Pflügers Archiv - European Journal of Physiology, 463(1), 121-137. doi:10.1007/s00424-011-1044-0

Beşirli, A. (2020). Relationships among anxiety and depression levels with sleep quality and insomnia severity in geriatric patients with depression. Southern Clinics of Istanbul Eurasia, 235-242. doi:10.14744/scie.2020.48403

Bingöl, O. (2014). Toplumsal cinsiyet olgusu ve türkiye'de kadınlık. Karamanoğlu Mehmetbey Üniversitesi Sosyal ve Ekonomik Araştırmalar Dergisi, 2014(3), 108-114. doi:10.18493/kmusekad.36760

Boysan, M., Güleç, M., Beşiroğlu, L., \& Kalafat, T. (2010). Psychometric properties of the insomnia severity index in Turkish sample. Anatol J Psychiatry, 11: 248-252.

Choueiry, N., Salamoun, T., Jabbour, H., El Osta, N., Hajj, A., \& Rabbaa Khabbaz, L. (2016). Insomnia and relationship with anxiety in university students: A cross-sectional designed study. PLOS ONE, 11(2). doi:10.1371/journal. pone.0149643

Esin, M.N. (2015). Örnekleme. Semra Erdoğan, Nursen Nahcivan, M. Nihal Esin (Ed.), Hemşirelikte Araştırma içinde (s.183), Nobel Tıp Kitabevleri. İstanbul.

Gupta, R., \& Pandi-Perumal, S. R. (2020). COVID-Somnia: How the pandemic affects sleep/wake regulation and how to deal with it? Sleep and Vigilance, 4(2), 51-53. doi:10.1007/s41782-020-00118-0

Inchausti, F., García-Poveda, N. V., Prado-Abril, J., \& Sánchez-Reales, S. (2020). La psicología Clínıca ante la pandemı covid-19 en España. Clínica Y Salud, 31(2), 105-107. doi:10.5093/clysa2020a11

Ithan Alp, S., Deveci, M., Erdal, B., Akalın, R. B., \& Terzi, D. (2020). Coronavirüs hastalığı 2019 (Covid 19) dönemi nde üniversite öğrencilerinde uyku kalitesi ve insomnia şiddet,. Namık Kemal Tıp Dergisi, 295-302. doi:10.37696/ nkmj.752847

Johnson, E. O., Roth, T., \& Breslau, N. (2006). The association of insomnia with anxiety disorders and depression: Exploration of the direction of risk. Journal of Psychiatric Research, 40(8), 700-708. doi:10.1016/j. jpsychires.2006.07.008

Köroğlu E. (2013) American Psychiatric Association, Diagnostic and Statistical Manual of Mental Disorders, Fifth Edition (DSM-5), From the Diagnostic Criteria Application Manual, Trans., Physicians Publications Association, Ankara.

Liu, S., Yang, L., Zhang, C., Xiang, Y., Liu, Z., Hu, S., \& Zhang, B. (2020). Online mental health services in China during the COVID-19 outbreak. The Lancet Psychiatry, 7(4). doi:10.1016/s2215-0366(20)30077-8

OECD. (n.d.). Gender Equality. Retrieved August 11, 2021, from http://www.oecd.org/gender/data/ balancingpaidworkunpaidworkandleisure.htm

Özdin, S., \& Bayrak Özdin, ş. (2020). Levels and predictors of anxiety, depression and health anxiety During covid-19 pandemic in Turkish society: The importance of gender. International journal of Social Psychiatry, 66(5), 504-511. doi:10.1177/0020764020927051

Rubin, G. J., \& Wessely, S. (2020). The psychological effects of quarantining a city. BMJ, M313. doi:10.1136/bmj.m313

Salcan, S., \& Sarıkaya, B. (2020). The prevalence of anxiety, insomnia and depression of pharmacy employees i n the covid-19 pandemic. Türkiye Halk Sağlığı Dergisi, 58-65. doi:10.20518/tjph.770288

Sağlık Hizmetleri Dairesi Başkanliği. Retrieved August 11, 2021, from https://khgmsaglikhizmetleridb.saglik.gov.tr/ TR-48633/bulasici-hastaliklar-ile-mucadele-rehberi---genelge-2018-22.html

Scotta, A. V., Cortez, M. V., \& Miranda, A. R. (2020). Insomnia is associated with Worry, Cognitive avoidance and low academic engagement in Argentınıan university students during the COVID-19 social isolation. Psychology, 
Health \& Medicine, 1-16. doi:10.1080/13548506.2020.1869796

Söğütlü, Y., Söğütlü, L., \& Göktaş, S. Ş. (2021). Relationship of covid-19 pandemic with anxiety, anger, sleep and emotion regulation in healthcare professionals. Journal of Contemporary Medicine, 11(1), 41-49. doi:10.16899/ jcm.804329

Şahiner Önal, G., Hisar, K. (2018). Üniversite öğrencilerinde uykusuzluk şiddeti ve depresyon semptomları ilişkisi ve depresyon tedavisinin uykusuzluk şiddetine etkisi. Gümüşhane Üniversitesi Sağlık Bilimleri Dergisi, 7 (1), 125-130. Retrieved from https://dergipark.org.tr/tr/pub/gumussagbil/issue/36260/398551

Şentürk, B. (2016). Çokuz ama yokuz: Türkiye'deki akademisyen kadınlar üzerine bir analiz. Viraverita E-Dergi, (2), 1-22. Retrieved from https://dergipark.org.tr/tr/pub/viraverita/issue/22434/240070

Turkish Public Health Institution. Community Health Center and Affiliated Units Regulation. Official Gazette No. 29258 dated February 5, 2015 : https://www.resmigazete.gov.tr/eskiler/2015/02/20150205-5.htm.

Turkish Ministry of Health, General Directorate of Public Health, Infectious Diseases Guide: https:// khgmsaglikhizmetleridb.saglik.gov.tr/TR-48633/bulasici-hastaliklar-ile-mucadele-rehberi--genelge-2018-22.html

Van Reeth, O., Weibel, L., Spiegel, K., Leproult, R., Dugovic, C., \& Maccari, S. (2000). Physiology of sleep (review)interactions between stress and sleep: From basic research to clinical situations. Sleep Medicine Reviews, 4(2), 201-219. doi:10.1053/smrv.1999.0097 
